\title{
Lung Cancer Clinical TNM Finding v8
}

National Cancer Institute

\section{Source}

National Cancer Institute. Lung Cancer Clinical TNM Finding v8. NCI Thesaurus. Code C136431.

A clinical finding about one or more characteristics of lung cancer, following the rules of the TNM AJCC v8 classification system. 